1 The Anthropogenic Consequences of Energy Consumption and Population Expansion in Africa? Do governance factors make any difference?

\title{
4 Abstract
}

5 Sub-Saharan Africa is greatly affected by global warming and is the most affected region in the world. Although several studies in the literature have attempted to identify the causative agents and recommendations to the environmental damages, the gap remains unfilled as the situation is still not any better. This study contributes to the existing body of knowledge through the investigation of the role of governance, energy consumption and population on the environmental quality in Sub-Saharan Africa using data spanning over the period 1998 to 2014 for 46 countries in the region. For the empirical analysis, the System-Generalised Method of

Moments (S-GMM) is employed to analyse the model. Findings from the study reveal that while the total population has a negative but insignificant impact on emissions, the urban population has a positive and statistically significant impact on emissions. The moderation effect of governance is found to overturn the adversities of the urban population on emissions, but this effect is statistically insignificant. The study recommends proper and strategic management of population pressure in urban centres to mitigate its impact on emissions

Keywords: Energy Consumption; Population; Governance; Sub-Saharan Africa; CO2 Emissions

\section{Introduction}

The role of population growth as a determinant of the rise in $\mathrm{CO}_{2}$ emissions appears to be substantial (Birdsall, 1992). $\mathrm{CO}_{2}$ emissions from human activities, especially energy consumption, have led to global climate change. This is because all human activities capable of generating GHGs such as; burning of fossil fuels are the causes of anthropogenic carbon emissions. Satterthwaite et al., (2009) believe that global warming is principally caused by people's consumption of goods and services whose production processes, distribution and consumption are capable of causing the emission of $\mathrm{CO}_{2}$. As a rule, an increase in population is accompanied by increasing levels of the supply of the aforesaid goods and services including energy usage. Therefore, population expansion is closely associated with anthropogenic $\mathrm{CO}_{2}$ emissions (Asumadu-sarkodie, 2016). 

population size, generally being at its peak when the population is at its highest (Chen et al. 2018; Yi et al., 2017). This is perhaps why Birdsall (1992) advocated that any energy policy aimed at cutting carbon emission should include fiscal spending on spending to cut the rates of population growth particularly in developing economies. Looking at the negative effects attributable to anthropogenic carbon emissions such as; shortage of water, air pollution increased sunlight intensity due to the depletion of the ozone layer, several studies have sought to provide evidence for factors accounting for this (Adedoyin et al., (2020); Adedoyin et al., (2020); Adedoyin et al., (2020); Adedoyin and Zakari (2020); Etokakpan et al., (2020); Kirikkaleli et al.

40 (2020); Udi et al., 2020)

This is because the environment is seen as a vital natural capital, hence, conserving it remains very primal. Consequent upon this, controlling anthropogenic $\mathrm{CO}_{2}$ emission occupies a central core of scientific research and energy policy globally. Presently, the various governments of every country as well as economic and political blocs have devoted so much resource and are so committed to curbing the mitigating effects of anthropogenic $\mathrm{CO}_{2}$ emission. Example of this commitment is the ratification of the Kyoto protocol in 1997 by 192 countries including SubSaharan Africa (SSA).

As the fight for control of anthropogenic carbon emissions is largely handled by the respective governments of different countries across the globe, empirics have shown that the quality of governance in the individual countries have a direct effect on the achievement of the targeted objective of reducing anthropogenic carbon emissions in the respective countries and the world at large (Halkos and Tzeremes, 2013; Bali et al., 2020; Omri and Bel, 2020). It is thus, plausible to say that, countries with effective governance such as; Singapore, Switzerland and Finland as shown by governance effectiveness index of World Bank (2018) will do better in controlling the anthropogenic consequence of energy consumption than those countries on the bottom of the table of good governance such as the SSA.

Short-termism, policy summersault or inconsistency, lack of policy implementation, fiscal indiscipline, high-level of corruption are some of the governance bottlenecks bedevilling the SSA. These shortcomings will no doubt have effects on the ability, of the SSA to achieve its aim of cutting or reducing emissions. As the SSA harbours countries with explosive population growth (e.g. Nigeria) which practically, increases the anthropogenic consequence of energy consumption, it is, therefore, imperative to access the moderating effects of the respective SSA

The over-reliance of the emerging economies such as the 
SSA on fossil fuels alongside the uncontrolled population experienced in the region has put the countries therein on the verge of environmental damages (Bekun et al,2019). As such, Bekun \& Agboola (2019) recommended for Nigeria as a member of the SSA to focus attention on the adoption of cleaner energy sources as a means to improve environmental sustainability and development.

However, going through various literature written on this area, to the best of our ability, none is seen to have considered this novelty at least not in the SSA. This kind of study is apt and timely and will be of immense benefit to both government and world leaders championing the cause of green world because it is believed that, even the legitimacy of global energy treaties such as the Kyoto protocol hinges on the strength of governance factors of the individual signatory nations (Hargrove et al., 2019). Therefore, the study will highlight areas of institutional strengths and weaknesses of the SSA in its fight to cut the consequences of the anthropogenic carbon emissions.

\section{Review of Literature}

\subsection{Emissions, Energy Consumption and Population Nexus}

The literature on anthropogenic carbon emission and population is vast and rich. Table 1 below shows a synopsis of some of the literature in this area. Generally, authors have applied different methodologies on diverse levels of data ranging from specific countries, regional as well as at the global level. The general outcome is that population derives increase in carbon emission by increasing the levels of energy consumption. This is plausible in the sense that an increase in population gears demand energy which naturally increases the release of $\mathrm{CO}_{2}$ in the atmosphere.

However, there is an exception to this conclusion in the work of Cui et al. (2019) conducted in China. Explanations offered to this is that, as the authors are dealing with the urban population, it was therefore seen that as the urban population increases over time technological progress helps in increasing efficient energy usage. This reduces energy demand as well as carbon emission in China.

The work of Cui et al. (2019) has therefore highlighted the salient fact that technologically advanced countries may record low consequence of anthropogenic energy consumption even in the presence of explosive population like China. It is therefore apriori expected that the contrariwise of China's case will apply for technologically backward nations such as the subject of this study - the SSA. In other words, an increase in population will 
significantly increase carbon emission in the SSA. This supposition is affirmed by the work of

97 Asumadu-Sarkodie and Owusu (2016) conducted in Ghana. It was empirically seen that 1\%

98 increase in population will derive the country's $\mathrm{CO}_{2}$ level by $1.72 \%$.

99 Table 1. Summary of literature on emissions, energy consumption and population

\begin{tabular}{|c|c|c|c|c|}
\hline Author(s) & Country/Region & Variables & Methodology & Results \\
\hline $\begin{array}{l}\text { Birdsall } \\
(1992)\end{array}$ & Global & $\begin{array}{l}\mathrm{CO}_{2} \\
\text { GNP }\end{array}$ & $\begin{array}{l}\text { Descriptive } \\
\text { statistics }\end{array}$ & $\begin{array}{l}\text { Reductions in population } \\
\text { will reduce } \mathrm{CO}_{2} \text { emissions }\end{array}$ \\
\hline $\begin{array}{l}\text { Knapp } \\
(1996)\end{array}$ & Global & $\begin{array}{l}\mathrm{CO}_{2} \\
\text { and } \\
\text { population }\end{array}$ & Causality & $\begin{array}{l}\text { Bi-directional causality } \\
\text { between } \mathrm{CO}_{2} \quad \text { and } \\
\text { population growth. }\end{array}$ \\
\hline $\begin{array}{l}\text { Zhu and } \\
\text { Peng (2012) }\end{array}$ & China & $\begin{array}{l}\mathrm{CO}_{2} \\
\text { emission, } \\
\text { population } \\
\text { size, } \\
\text { population } \\
\text { structure and } \\
\text { consumption } \\
\text { level. }\end{array}$ & $\begin{array}{l}\text { Ridge } \\
\text { regression } \\
\text { method }\end{array}$ & $\begin{array}{l}\text { Population Granger causes } \\
\mathrm{CO}_{2} \text { emissions, }\end{array}$ \\
\hline $\begin{array}{l}\text { Zhou and } \\
\text { Liu (2016) }\end{array}$ & China & $\begin{array}{l}\text { Population, } \\
\text { income, } \\
\text { energy } \\
\text { consumption, } \\
\mathrm{CO}_{2} \\
\text { emissions }\end{array}$ & $\begin{array}{l}\text { STIRPAT } \\
\text { model }\end{array}$ & $\begin{array}{l}\text { Population derives energy } \\
\text { consumption } \\
\text { emissions }\end{array}$ \\
\hline $\begin{array}{l}\text { Asumadu- } \\
\text { Sarkodie } \\
\text { and Owusu } \\
(2016)\end{array}$ & Ghana & $\begin{array}{l}\mathrm{CO}_{2} \\
\text { emissions } \\
\text { GDP, EU- } \\
\text { energy, } \\
\text { population } \\
\text { growth. }\end{array}$ & $\begin{array}{l}\text { VECM and } \\
\text { ARDL }\end{array}$ & $\begin{array}{l}1 \% \text { increase in population } \\
\text { spurs emission by } 1.72 \%\end{array}$ \\
\hline $\begin{array}{l}\text { Dong et al. } \\
(2018)\end{array}$ & Global & $\begin{array}{l}\mathrm{CO}_{2} \\
\text { size, population } \\
\text { and renewable } \\
\text { energy } \\
\text { intensity }\end{array}$ & $\begin{array}{l}\text { Panel } \\
\text { cointegration } \\
\text { test }\end{array}$ & $\begin{array}{l}\text { Population increases } \mathrm{CO}_{2} \\
\text { emissions }\end{array}$ \\
\hline Cui et al. & China & $\mathrm{CO}_{2}$ & $\begin{array}{l}\text { panel } \\
\text { threshold }\end{array}$ & Population \\
\hline
\end{tabular}




\begin{tabular}{|c|c|c|c|c|}
\hline (2019) & & $\begin{array}{l}\text { emission, } \\
\text { Urban } \\
\text { population } \\
\text { size and } \\
\text { behaviour } \\
\text { control } \\
\text { variables }\end{array}$ & regression & decreases $\mathrm{CO}_{2}$ emission. \\
\hline $\begin{array}{l}\text { Hashmi } \\
\text { and Alam } \\
(2019)\end{array}$ & $\begin{array}{l}\text { OECD } \\
\text { countries }\end{array}$ & $\begin{array}{l}\mathrm{CO}_{2} \\
\text { emissions; } \\
\text { population; } \\
\text { GDP; } \\
\text { environmental } \\
\text { patent and tax }\end{array}$ & GMM & $\begin{array}{l}\text { Population } \\
\text { Increases } \\
\text { emissions. }\end{array}$ \\
\hline $\begin{array}{l}\text { Mafizur, } \\
\text { Saidi and } \\
\text { Ben }(2020)\end{array}$ & $\begin{array}{l}\text { five South Asian } \\
\text { countries }\end{array}$ & $\begin{array}{l}\mathrm{CO}_{2} \text {, } \\
\text { population, } \\
\text { trade, and } \\
\text { GDP }\end{array}$ & $\begin{array}{l}\text { panel co- } \\
\text { integration } \\
\text { approach }\end{array}$ & $\begin{array}{l}\text { Causality runs from } \\
\text { population to } \mathrm{CO}_{2} \\
\text { emissions }\end{array}$ \\
\hline
\end{tabular}

\subsection{Emissions and Governance Factors}

Looking closely at table 2 , it is clear that the literature on governance and emissions has global coverage. There is a consensus among all the works reviewed on the effect of governance on emission. The works so far reviewed have shown a negative relationship between governance and emission. In other words, effective and favourable governance outcomes come with attendant effect of decreasing the anthropogenic consequence of energy consumption in the countries and regions studied.

For example, the study of Awais and Wang (2019) in BRICS reported a negative relationship between governance and emission. Because the economic system in the BRICS is mature, the governance system has an incentive system that regulates any market failure that

111 might lead to environmental degradation (Awais and Wang, 2019). Governance factors were

112 found to help institutionalize as well as in the implementation of environmental laws that help in 113 curbing $\mathrm{CO}_{2}$ levels in the economic bloc. The result of Halkos and Tzeremes (2013) conducted 114 in the G-20 countries conforms with these facts as reported in Awais and Wang (2019)

115 Similar results are recorded in 47 SSA, 23 emerging economies as well as across the 116 globe, by Asumadu, Adams, and Leirvik (2020), Omri and Bel (2020) and Bali, Kambhampati, 117 and Karimu (2020) respectively. Notwithstanding, the negative and favourable significance of 118 governance on emission levels, it is seen that the six governance factors; (voice and 
accountability, government effectiveness, political stability, control of corruption, rule of law and regulatory control) have different dimensions of affecting the level emission. Their effects on the emission level are at varying degrees. For instance, in Halkos and Tzeremes (2013), although control of corruption and rule of law are seen to have led to a decrease in $\mathrm{CO}_{2}$, control of corruption has a higher impact. While political stability appears to be a positive driver of emission, the voice of accountability is neutral in its effect.

126 the globe confirmed that amongst the six governance variables, only control of corruption has a

127 negative significant effect on anthropogenic $\mathrm{CO}_{2}$. This means that the more controlled 128 corruption is in an economy, the cleaner the economy from $\mathrm{CO}_{2}$ and vice versa.

Table 2. literature on emissions and governance factors

\begin{tabular}{|c|c|c|c|c|}
\hline Author(s)/Year & Country/Region & Variables & Methodology & Results \\
\hline $\begin{array}{l}\text { Halkos and } \\
\text { Tzeremes (2013) }\end{array}$ & $G-20$ & $\begin{array}{l}\mathrm{CO}_{2} \\
\text { and governance } \\
\text { factors }\end{array}$ & $\begin{array}{l}\text { non- } \\
\text { parametric } \\
\text { technique }\end{array}$ & $\begin{array}{l}\text { Good } \\
\text { governance } \\
\text { lowers emission } \\
\text { levels }\end{array}$ \\
\hline $\begin{array}{l}\text { Awais and Wang } \\
\text { (2019) }\end{array}$ & BRICS & $\begin{array}{l}\mathrm{CO}_{2}, \quad \text { GDP, } \\
\text { Government } \\
\text { Effectiveness, } \\
\text { Political stability, } \\
\text { corruption, rule } \\
\text { of law, regulatory } \\
\text { control }\end{array}$ & $\begin{array}{l}\text { Westerlund } \\
\text { panel Co- } \\
\text { integration }\end{array}$ & $\begin{array}{l}\text { Governance } \\
\text { decreases } \mathrm{CO}_{2}\end{array}$ \\
\hline $\begin{array}{l}\text { Hargrove, } \\
\text { Qandeel and } \\
\text { Sommer (2019) }\end{array}$ & $\begin{array}{l}\text { Global } \\
\text { nations }\end{array}$ & $\begin{array}{l}\mathrm{CO}_{2} \\
\text { Treaty } \\
\text { Ratifications and } \\
\text { governance } \\
\text { factors }\end{array}$ & $\begin{array}{l}\text { 2-way fixed } \\
\text { effects } \\
\text { regression }\end{array}$ & $\begin{array}{lr}\text { Climate } & \text { treaties } \\
\text { are associated } \\
\text { with } & \text { larger } \\
\text { decreases } & \text { in } \\
\text { emissions } & \text { in } \\
\text { nations } & \text { with }\end{array}$ \\
\hline
\end{tabular}




\begin{tabular}{|c|c|c|c|c|}
\hline & & & & $\begin{array}{l}\text { higher levels of } \\
\text { state governance. }\end{array}$ \\
\hline $\begin{array}{l}\text { Asumadu, } \\
\text { Adams and } \\
\text { Leirvik (2020) }\end{array}$ & 47 SSA countries & $\begin{array}{l}\mathrm{CO}_{2} \text { emissions, } \\
\text { GDP, FDI, } \\
\text { renewable energy } \\
\text { and governance. }\end{array}$ & $\begin{array}{l}\text { Panel co- } \\
\text { integration } \\
\text { technique }\end{array}$ & $\begin{array}{l}\text { Governance } \\
\text { negatively affects } \\
\text { emissions }\end{array}$ \\
\hline $\begin{array}{l}\text { Bali, } \\
\text { Kambhampati } \\
\text { and Karimu } \\
(2020)\end{array}$ & $\begin{array}{l}\text { Global, } \\
\text { countries }\end{array}$ & $\begin{array}{l}\text { Environmental } \\
\text { variables, } \\
\text { governance } \\
\text { factors and the } \\
\text { informal } \\
\text { economy }\end{array}$ & GMM & $\begin{array}{l}\text { Governance } \\
(\mathrm{CoP}) \text { improves } \\
\text { environmental } \\
\text { quality in the } \\
\text { non-OECD }\end{array}$ \\
\hline $\begin{array}{l}\text { Omri and Bel } \\
(2020)\end{array}$ & $\begin{array}{l}23 \text { emerging } \\
\text { economies }\end{array}$ & $\begin{array}{l}\mathrm{CO}_{2} \\
\text { emissions, FDI, } \\
\text { governance } \\
\text { quality and } \\
\text { Technological } \\
\text { innovation. }\end{array}$ & System-GMM & $\begin{array}{l}\text { Governance } \\
\text { decrease the level } \\
\text { of } \mathrm{CO}_{2} \\
\text { emissions. }\end{array}$ \\
\hline
\end{tabular}

3. Data and Methods

$134 \quad 3.1$ Data and Variables

136 in table 3 below.

137 Table 3. Description of Variables

\begin{tabular}{|l|l|l|}
\hline Code & Variable & Source
\end{tabular}

\footnotetext{
${ }^{1}$ Unavailability of data on governance factors and emissions sets this limitation.
} 


\begin{tabular}{|c|c|c|}
\hline RGDP & GDP per capita, constant 2010 dollars & The World Bank \\
\hline ROL & Rule of law index ( -2.5 weak; 2.5 strong) & The World Bank \\
\hline GEI & Government effectiveness index (-2.5 weak; 2.5 strong) & The World Bank \\
\hline $\mathrm{COC}$ & Control of corruption (-2.5 weak; 2.5 strong) & The World Bank \\
\hline RQI & Regulatory quality index (-2.5 weak; 2.5 strong) & The World Bank \\
\hline VAI & Voice and accountability index ( -2.5 weak; 2.5 strong $)$ & The World Bank \\
\hline PSI & Political stability index (-2.5 weak; 2.5 strong) & The World Bank \\
\hline $\mathrm{CO} 2$ & Carbon dioxide emissions per capita & The World Bank \\
\hline ENC & Energy Consumption, thousands barrel per day & $\begin{array}{l}\text { The U.S. Energy } \\
\text { Information } \\
\text { Administration }\end{array}$ \\
\hline TPOP & Population size, in millions & $\begin{array}{l}\text { United Nations } \\
\text { Population Division }\end{array}$ \\
\hline UPOP & Percent urban population & $\begin{array}{l}\text { United Nations } \\
\text { Population Division }\end{array}$ \\
\hline RPOP & Rural population, per cent of the total population & The World Bank \\
\hline
\end{tabular}

\subsection{Model and Methods}

An econometric analysis with the use of a panel data model is vital for insightful policymaking (Adedoyin et al., 2020). Hence, this study covers several countries, it is mandatory to utilize panel data analysis. Given that the number of countries under study is relatively larger

145 than the period of the study $(\mathrm{N}>\mathrm{T})$, it justifies the use of the system-GMM (Generalized 146 Method of Moments). The system-GMM is more suitable for a larger set of panel studies compared to other econometric approaches. methodologies such as; the LS technique, 2SLS, IV regression technique among others because it 
yields more consistent and efficient estimate particularly in models characterised with serial correlation and heteroscedasticity (F. F. Adedoyin et al., 2017).

Besides, several pre and post diagnostics tests were carried out. The pre-diagnostics include; a summary statistic- gives the full picture of the panel, the pair-wise correlation matrixthat shows the level of association among the variables, bin scatter plots- to show us the tolerability of our standard error. The post-estimation diagnostics conducted are; the Hansen and Sargan test to ascertain the instruments' validity as well as to test for auto and serial correlation of the error term to ensure the reliability of the moment conditions.

\subsection{Model Specification}

To estimate the impact of governance, energy consumption and population on emissions, the following equation is specified;

\section{LCO2 = f (LRGDP, LPOP, LENC, GOV)}

$$
L C 02=\alpha_{0}+\beta_{1} L R G D P_{i t}+\beta_{2} L P O P_{i t}+\beta_{3} L E N C_{i t}+\beta_{4} G O V_{i t}+\varepsilon_{i t}
$$

In our attempt to ensure a constant variance as much as possible, most of the variables undergo a logarithmic transformation. Where LC02, LRGDP, LENC, GOV are the variables and $\varepsilon_{i t}, \alpha$ and $\beta$ 's represents the stochastic, intercept, and partial slope coefficients respectively.

\section{Results, Discussions and Implications of Research Findings}

Table 2 presents the summary statistics for the variables. As can be seen, LRGDP has the highest average value and single maximum observation, while LC02 is the most dispersed variable. Political stability records the least single value among the observations. Table 3 presents the results for the Pearson correlation matrix. The matrix reveals that there is a linear association between the dependent variable LC02 and LRGDP, LENC, ROL, GEI, COC, RQI, VAI, PSI and GOV. On the other hand, there is a negative association between LTPOP and the dependent variable LC02.

Table 4. Summary Statistics

\begin{tabular}{|l|l|l|l|l|l|}
\hline Variable & Obs. & Mean & $\begin{array}{l}\text { Std. } \\
\text { Dev. }\end{array}$ & Min & Max \\
\hline LCO2 & 779 & -1.257 & 1.424 & -3.912 & 2.301 \\
\hline LRGDP & 757 & 7.009 & 1.041 & 5.234 & 9.930 \\
\hline
\end{tabular}




\begin{tabular}{|l|l|l|l|l|l|}
\hline LENC & 782 & 2.640 & 1.400 & -0.511 & 6.791 \\
\hline LTPOP & 779 & 1.908 & 1.572 & -2.526 & 5.173 \\
\hline ROL & 690 & -0.721 & 0.683 & -2.610 & 1.080 \\
\hline GEI & 690 & -0.760 & 0.631 & -2.450 & 1.040 \\
\hline COC & 690 & -0.638 & 0.627 & -1.870 & 1.220 \\
\hline RQI & 690 & -0.706 & 0.653 & -2.650 & 1.130 \\
\hline VAI & 690 & -0.591 & 0.749 & -2.230 & 1.010 \\
\hline PSI & 690 & -0.542 & 0.966 & -3.310 & 1.280 \\
\hline GOV & 690 & -0.660 & 0.648 & -2.450 & 0.882 \\
\hline
\end{tabular}

176

177 
Table 5. Correlation Matrix

\begin{tabular}{|c|c|c|c|c|c|c|c|c|c|c|c|}
\hline & LCO2 & LRGDP & LENC & LTPOP & ROL & GEI & $\mathrm{COC}$ & RQI & VAI & PSI & GOV \\
\hline $\mathrm{LCO} 2$ & 1 & & & & & & & & & & \\
\hline \multirow[t]{2}{*}{ LRGDP } & $0.9115^{*}$ & 1 & & & & & & & & & \\
\hline & 0 & & & & & & & & & & \\
\hline \multirow{2}{*}{ LENC } & $0.3212^{*}$ & $0.2408 *$ & 1 & & & & & & & & \\
\hline & 0 & 0 & & & & & & & & & \\
\hline \multirow[t]{2}{*}{ LTPOP } & $-0.4062^{*}$ & $-0.4340^{*}$ & $0.6766^{*}$ & 1 & & & & & & & \\
\hline & 0 & 0 & 0 & & & & & & & & \\
\hline \multirow[t]{2}{*}{ ROL } & $0.4500^{*}$ & $0.3943 *$ & 0.1277* & $-0.2853^{*}$ & 1 & & & & & & \\
\hline & 0 & 0 & 0.0008 & 0 & & & & & & & \\
\hline \multirow[t]{2}{*}{ GEI } & $0.5014^{*}$ & 0.4219* & 0.2949* & $-0.1654^{*}$ & 0.9111* & 1 & & & & & \\
\hline & 0 & 0 & 0 & 0 & 0 & & & & & & \\
\hline \multirow[t]{2}{*}{$\mathrm{COC}$} & $0.4278^{*}$ & $0.3468^{*}$ & 0.0443 & $-0.3612^{*}$ & 0.8854* & $0.8584^{*}$ & 1 & & & & \\
\hline & 0 & 0 & 0.245 & 0 & 0 & 0 & & & & & \\
\hline \multirow[t]{2}{*}{ RQI } & $0.3814^{*}$ & $0.3335^{*}$ & $0.3115^{*}$ & -0.0604 & 0.8738* & 0.8799* & $0.7423^{*}$ & 1 & & & \\
\hline & 0 & 0 & 0 & 0.114 & 0 & 0 & 0 & & & & \\
\hline \multirow[t]{2}{*}{ VAI } & $0.3774 *$ & $0.2865^{*}$ & 0.1384* & $-0.2343 *$ & $0.8425^{*}$ & $0.7772^{*}$ & $0.7469 *$ & $0.7900^{*}$ & 1 & & \\
\hline & 0 & 0 & 0.0003 & 0 & 0 & 0 & 0 & 0 & & & \\
\hline \multirow[t]{2}{*}{ PSI } & $0.5260^{*}$ & $0.4829 *$ & $-0.0939 *$ & $-0.5107^{*}$ & 0.7917* & $0.6854^{*}$ & 0.6939* & $0.6504^{*}$ & $0.6977 *$ & 1 & \\
\hline & 0 & 0 & 0.0136 & 0 & 0 & 0 & 0 & 0 & 0 & & \\
\hline GOV & $0.4964^{*}$ & $0.4285^{*}$ & $0.1331 *$ & $-0.3175^{*}$ & $0.9715^{*}$ & $0.9280^{*}$ & $0.8965^{*}$ & $0.8972^{*}$ & $0.8927 *$ & $0.8538^{*}$ & 1 \\
\hline
\end{tabular}


180 Figure 1. Bin Scatter Plots

181
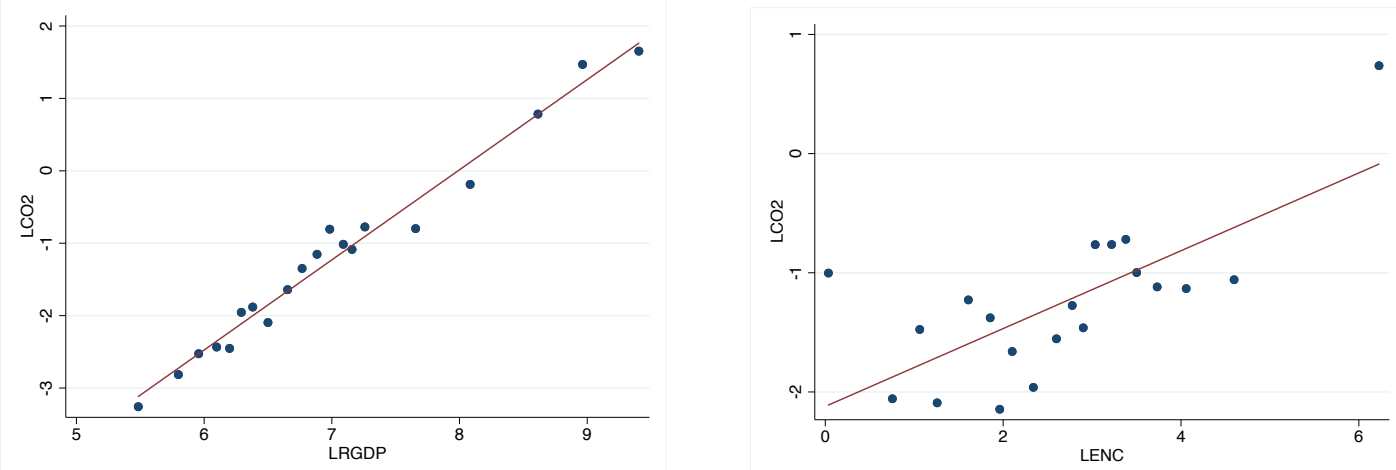

182

183
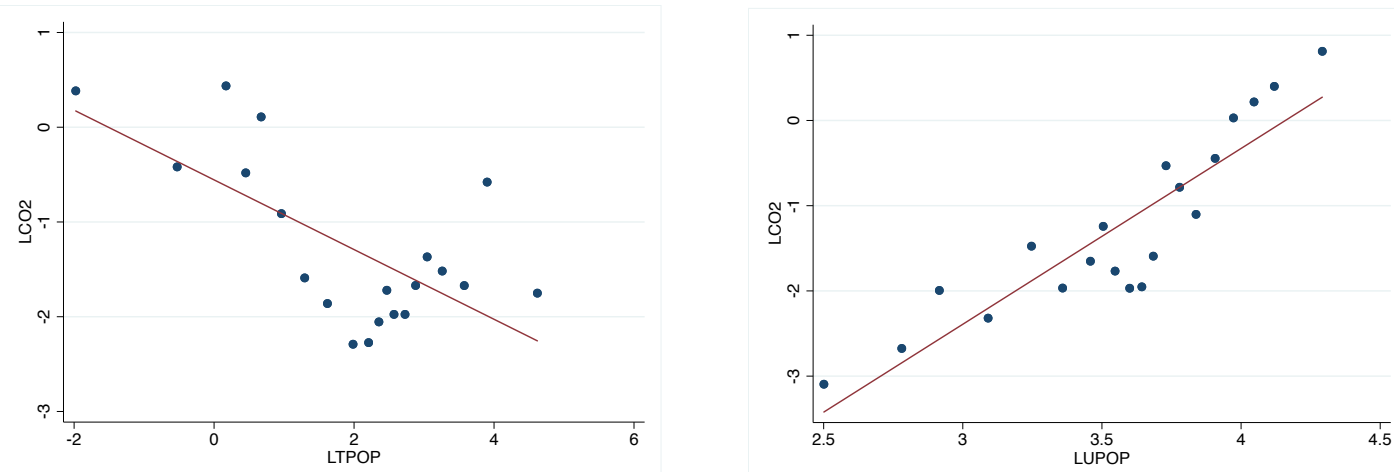

184

185

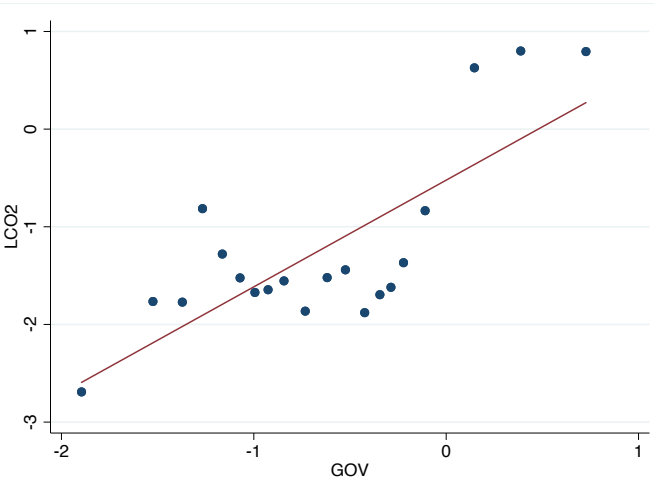

Table 6 presents the estimation results for the model. The model is consistent with 188 previous studies and is significant. The results reveal that economic growth has a positive impact 189 on emissions at a $1 \%$ level of significance. This finding is similar to that of Acheampong (2018) for 116 countries and Bakhsh et. al. (2017) for Pakistan. Specifically, a $1 \%$ rise in economic growth is associated with a $0.923 \%$ increase in emission. This implies that continuous economic 
192

193

194

195

196

197

198

199

200

201

202

203

204

205

206

207

208

209

210

211

212

213

214

215

216

217

218

219

220

221

222

223

224

expansion in sub-Saharan Africa will give rise to the level of emissions in the environment thus depleting the quality of the environment. Subsequently, this points to the fact that economic activities as having been practised over the years involve carbon-emitting processes that harm the environment. On the other hand, energy consumption has a positive impact on emissions at a 5\% level of significance. This finding corroborates those of Eggoh et al. (2011) for 21 African

countries and Shabaz et al. (2013) for Indonesia. A 1\% rise in energy consumption will be accompanied by a $0.03 \%$ rise in emissions which implies that energy consumption in Africa is detrimental to the quality of the environment as it triggers a rise in emissions in the region. This could be because energy consumption in the region is comprised highly of carbon-emitting energy resources like fossil fuels and coal.

On the other hand, the total population has a negative but insignificant impact on emissions in the region. This entails that the influence of population on emissions is not significant. Among all government indicators, Rule of law, Control of Corruption and Regulatory Quality have a negative but insignificant impact on emissions. While government effectiveness and Voice and Accountability have a positive but insignificant impact on emissions. Only Political Stability appears to have a significant impact on emission which is a positive impact. This implies that emissions are sensitive to political stability in sub-Saharan Africa and that an improvement in political transition triggers an increase in the level of emissions. This could be because peaceful political transitions send positive signals to the economy which leads to an expansion in economic activities.

In the second model, we include the interaction term between governance and population. We find that again, economic growth leads to an increase in emissions at a $1 \%$ level of significance. This confirms that economic activities are an important trigger of emissions in the region. Similarly, energy consumption also has a positive impact on emissions at a $10 \%$ level of significance. This result agrees with that of model 1, thus, confirming that energy consumption contributes to rising emissions in sub-Saharan Africa.

The impact of the total population on emissions is negative but insignificant. A similar result was obtained in model 1. This implies that the population is not important in explaining changes in the level of emissions in the sub-Saharan Africa region. The interaction term between population and governance has a positive but statistically insignificant impact on emissions. This entails that even with the combination of governance and population has no significant impact on emissions. 
225 Table 6. Results of Dynamic System GMM for Total Population

\begin{tabular}{|c|c|c|}
\hline & (1) & (2) \\
\hline VARIABLES & $\mathrm{LCO} 2$ & $\mathrm{LCO} 2$ \\
\hline \multirow[t]{2}{*}{ L.LCO2 } & $0.923 * * *$ & $0.930 * * *$ \\
\hline & $(0.0738)$ & $(0.0710)$ \\
\hline \multirow[t]{2}{*}{ L2.LCO2 } & 0.00653 & 0.00164 \\
\hline & $(0.0696)$ & $(0.0676)$ \\
\hline \multirow[t]{2}{*}{ LRGDP } & $0.0497 * * *$ & $0.0507 * * *$ \\
\hline & $(0.0136)$ & $(0.0143)$ \\
\hline \multirow[t]{2}{*}{ LENC } & $0.0323 *$ & $0.0328^{*}$ \\
\hline & $(0.0181)$ & $(0.0184)$ \\
\hline \multirow[t]{2}{*}{ LTPOP } & -0.0224 & -0.0214 \\
\hline & $(0.0148)$ & $(0.0142)$ \\
\hline \multirow[t]{2}{*}{ ROL } & -0.0225 & \\
\hline & $(0.0286)$ & \\
\hline \multirow[t]{2}{*}{ GEI } & 0.0308 & \\
\hline & $(0.0271)$ & \\
\hline \multirow[t]{2}{*}{$\mathrm{COC}$} & -0.0165 & \\
\hline & $(0.0151)$ & \\
\hline \multirow[t]{2}{*}{ RQI } & -0.00650 & \\
\hline & $(0.0183)$ & \\
\hline \multirow[t]{2}{*}{ VAI } & 0.00478 & \\
\hline & $(0.0100)$ & \\
\hline \multirow[t]{2}{*}{ PSI } & $0.0224 *$ & \\
\hline & $(0.0129)$ & \\
\hline \multirow[t]{2}{*}{ LTPOPGOV } & & 0.00578 \\
\hline & & $(0.00495)$ \\
\hline \multirow[t]{2}{*}{ GOV } & & 0.00302 \\
\hline & & $(0.0153)$ \\
\hline \multirow[t]{2}{*}{ Constant } & $-0.448^{* * *}$ & $-0.451 * * *$ \\
\hline & $(0.140)$ & $(0.145)$ \\
\hline Observations & 626 & 626 \\
\hline Number of countryid & 45 & 45 \\
\hline
\end{tabular}




\begin{tabular}{|l|l|l|}
\hline AR $(1)$ z Test Statistic & -4.48 & -4.50 \\
\hline AR (1) P value & 1.33 & 0.000 \\
\hline AR $(2)$ z Test Statistic & 0.000 & 1.35 \\
\hline AR (2) P value & 0.184 & 0.179 \\
\hline $\begin{array}{l}\text { Sargan test Chi2 } \\
\text { Sargan P value }\end{array}$ & 300.35 & 303.20 \\
\hline Hansen test Chi2 & 0.123 & 0.101 \\
\hline $\begin{array}{l}\text { Hansen P value } \\
\text { Robust standard errors in parentheses } \\
* * *\end{array}<<0.01, * * \mathrm{p}<0.05, * \mathrm{p}<0.1$ & 34.83 & 36.63 \\
\hline
\end{tabular}

226

In table 7 we use the urban population as a proxy for pollution in the two models and while the results are for most of the variables are similar to those obtained in table 6 , those for the population are different. Beginning with economic growth, results reveal a positive relationship between economic growth and emissions in Sub-Saharan Africa as already obtained in table 6. Similarly, energy consumption has a positive impact on emissions as already recorded in table 6. On the other hand, the urban population has a positive impact on emissions. This result is unique compared to the findings of several studies that the population has no impact on emissions. Specifically, a $1 \%$ rise in urban population will bring about a $0.038 \%$ increase in emissions in the region. This implies that as urban population rise, they bring about a rise in emissions. This result is in line with the findings of Alam, et al (2016) for India and Brazil and Asumadu-Sarkodie and Owusu (2016) for Ghana. According to Abdallah and Abugamos (2017), as the urban population grows, there is an increase in manufacturing and construction activities in the urban areas hence these activities constitute an increase in the level of emissions. The governance indicators (ROL, COC, VAI, RQI, PSI, GEI, ) in the model have no significant impact on emissions.

In the second model, where the interaction term between urban population and governance is included in the model, results reveal that economic growth continues to lead to a rise in emissions by an average of $0.927 \%$. Similarly, energy consumption has a positive impact on emissions. A $1 \%$ rise in energy consumption will be accompanied by a $0.0091 \%$ increase in the level of emissions in the region. Unlike results in model 1, the urban population has a positive but insignificant impact on emissions. This could be as a result of the inclusion of the interaction term in the model. To support this position, the interaction term between urban population and governance hurts emissions but this impact is statistically insignificant. However, 
250 this points to the fact that an improvement in governance is capable of overturning the adverse

251 impact of the urban population on emissions in Sub-Saharan Africa, even though such influence

252 is not statistically notable. On the other hand, governance has a positive but insignificant impact on emissions.

254

255

Table 7. Results of Dynamic System GMM for Urban Population

\begin{tabular}{|l|l|l|}
\hline & $(1)$ & $(2)$ \\
\hline VARIABLES & LCO2 & LCO2 \\
\hline L.LCO2 & $0.919 * * *$ & $0.927 * * *$ \\
\hline L2.LCO2 & $(0.0735)$ & $(0.0733)$ \\
\hline & 0.0174 & 0.0136 \\
\hline LRGDP & $(0.0706)$ & $(0.0706)$ \\
\hline & $0.0488^{* * *}$ & $0.0486 * *$ \\
\hline LENC & $(0.0141)$ & $(0.0125)$ \\
\hline & $0.00982 *$ & $0.00909 * *$ \\
\hline LUPOP & $(0.00564)$ & $(0.00353)$ \\
\hline & $0.0384 * *$ & 0.0323 \\
\hline ROL & $(0.0182)$ & $(0.0266)$ \\
\hline & -0.00643 & \\
\hline GEI & $(0.0296)$ & \\
\hline VAS & 0.0432 & \\
\hline COC & $(0.0263)$ & \\
\hline & -0.0244 & \\
\hline RQI & $(0.0168)$ & \\
\hline & -0.0135 & \\
\hline & $(0.0191)$ & \\
\hline & 0.00604 & \\
\hline & $(0.0115)$ & \\
\hline & 0.0197 & \\
\hline & $(0.0132)$ & \\
\hline & & \\
\hline
\end{tabular}




\begin{tabular}{|l|l|l|}
\hline & & $(0.0812)$ \\
\hline Constant & $-0.541 * * *$ & $-0.510^{* * *}$ \\
\hline & $(0.159)$ & $(0.177)$ \\
\hline Observations & 626 & 626 \\
\hline Number of countryid & 45 & 45 \\
\hline Post-estimation Diagnostics & & -4.49 \\
\hline AR $(1)$ z Test Statistic & -4.50 & 0.000 \\
\hline AR $(1)$ P value & 0.000 & 1.24 \\
\hline AR $(2)$ z Test Statistic & 1.24 & 0.216 \\
\hline AR $(2)$ P value & 0.216 & 286.33 \\
\hline Sargan test Chi2 & 287.34 & 0.187 \\
\hline \begin{tabular}{l} 
Sargan P value \\
\hline Hansen test Chi2
\end{tabular} & 0.176 & 38.47 \\
\hline Hansen P value & 32.93 & 1.000 \\
\hline $\begin{array}{l}\text { Robust standard errors in parentheses } \\
* * *\end{array}<0.01, * * \mathrm{p}<0.05, * \mathrm{p}<0.1$ & 1.000 & \\
\hline
\end{tabular}

\section{Conclusion and Policy Directions}

Sub-Saharan Africa remains the worst affected region by global warming. While several studies have been carried out to identify causes and solutions to the environmental crisis. Our study seeks to investigate the role of governance, energy consumption and population on the environmental quality in sub-Saharan Africa is investigated using data spanning over the period 1998 to 2014 for 46 countries in the region. The System-Generalised Method of Moments is used to analyse the model. According to the findings from the study, while the total population has a negative but insignificant impact on emissions, the urban population has a positive and statistically significant impact on emissions. The moderation effect of governance overturns the adverse impact of the urban population on emissions, but this effect is statistically insignificant. Energy consumption has a positive impact on emissions in the region. having established that urban population pressures could aggravate emissions in the region, by stimulating demand for economic goods and services such as transportation, housing, food and

271 other services. In response to these demands, there is a rise in manufacturing and construction activities which gives rise to emissions.

This study, therefore, recommends that the governments 
Similarly, the adoption of a sustainable transport system in urban centres such as electric trains

will go a long way to reduce emissions associated with transiting a high population of people in cities. The results from the study also indicated that an improvement in the quality of governance can mitigate the adverse impact of the urban population on emissions in the environment. To this effect, it is suggested that quality governing initiatives be adopted to manage the urban population and its impact on the environment.

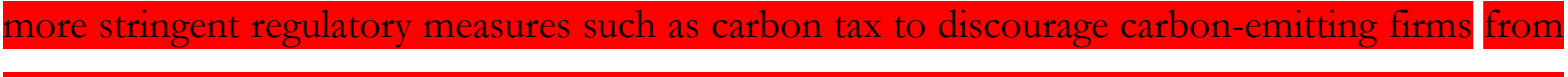

adoption of cleaner energy sources as alternatives in the region. The use of renewable energy will

aid will lead to a reduction in the level of emissions thus improving the quality of the natural environment in the region.

\section{References}

Adedoyin, F., Abubakar, I., Victor, F., \& Asumadu, S. (2020). Generation of energy and environmental-economic growth consequences: Is there any difference across transition economies ? Energy Reports, 6, 1418-1427. https://doi.org/10.1016/j.egyr.2020.05.026

Adedoyin, F. F., Alola, A. A., \& Bekun, F. V. (2020). An assessment of environmental sustainability corridor: The role of economic expansion and research and development in EU countries. Science of the Total Environment, 713, 136726. https://doi.org/10.1016/j.scitotenv.2020.136726

Adedoyin, F. F., Bekun, F. V., \& Alola, A. A. (2020). Growth Impact of Transition from Nonrenewable to Renewable Energy in the EU: The role of Research and Development Expenditure. Renewable Energy.

Adedoyin, F. F., Cheol, L., Adeniyi, O., \& Kabir, M. (2017). Oil rents and fiscal balance in oil dependent economies: do fiscal rules matter? Asian Journal of Empirical Research, 7(8), 176201. https://doi.org/10.18488/journal.1007/2017.7.8/1007.8.176.201

Adedoyin, F. F., Gumede, I. M., Bekun, V. F., Etokakpan, U. M., \& Balsalobre-lorente, D. (2020a). Modelling coal rent, economic growth and CO2 emissions: Does regulatory quality matter in BRICS economies? Science of the Total Environment, 710, 136284. https://doi.org/10.1016/j.scitotenv.2019.136284

Adedoyin, F. F., Gumede, M. I., Bekun, F. V., Etokakpan, M. U., \& Balsalobre-lorente, D. (2020b). Modelling coal rent, economic growth and CO2 emissions: Does regulatory quality matter in BRICS economies? Science of the Total Environment, 710, 136284. https://doi.org/10.1016/j.scitotenv.2019.136284

Adedoyin, F. F., \& Zakari, A. (2020). Energy Consumption, Economic Expansion, and CO2 Emission in the UK: The Role of Economic Policy Uncertainty. Science of The Total 
Environment.

https://www.researchgate.net/publication/341902809_Energy_Consumption_Economic_ Expansion_and_CO2_Emission_in_the_UK_The_Role_of_Economic_Policy_Uncertainty

Adedoyin, F., Ozturk, I., Abubakar, I., Kumeka, T., \& Folarin, O. (2020). Structural breaks in CO 2 emissions: Are they caused by climate change protests or other factors? Journal of $\begin{array}{lll}\text { Environmental } \quad \text { Management, 266(December } & \text { 2019), } & 110628 .\end{array}$ https://doi.org/10.1016/j.jenvman.2020.110628

Asumadu-sarkodie, S. (2016). Carbon dioxide emissions , GDP , energy use , and population growth : a multivariate and causality analysis for Ghana, 1971 - 2013. Environmental Science and Pollution Research, 13508-13520. https://doi.org/10.1007/s11356-016-6511-x

Awais, M., \& Wang, B. (2019). Analyzing the role of governance in CO 2 emissions mitigation: The BRICS experience. Structural Change and Economic Dynamics, 51, 119-125. https://doi.org/10.1016/j.strueco.2019.08.007

Bali, R., Kambhampati, U. S., \& Karimu, A. (2020). Regulation, governance and the role of the informal sector in in fl uencing environmental quality? Ecological Economics, 173(March), 106649. https://doi.org/10.1016/j.ecolecon.2020.106649

Bekun, F. V., \& Agboola, M. O. (2019). Electricity Consumption and Economic Growth Nexus : Evidence from Maki Cointegration. 30(1), 14-23.

Bekun, F. V., Emir, F., \& Sarkodie, S. A. (2019). Another look at the relationship between energy consumption, carbon dioxide emissions, and economic growth in South Africa. Science of the Total Environment, 655, 759-765. https://doi.org/10.1016/j.scitotenv.2018.11.271

Cui, P., Xia, S., \& Hao, L. (2019). Do different sizes of urban population matter differently to CO 2 emission in different regions? Evidence from electricity consumption behavior of urban residents in China. Journal of Cleaner Production, 240, 118207. https://doi.org/10.1016/j.jclepro.2019.118207

Dong, K., Hochman, G., Zhang, Y., Sun, R., Li, H., \& Liao, H. (2018). CO2 emissions, economic and population growth, and renewable energy: Empirical evidence across regions. Energy Economics, 75, 180-192. https://doi.org/10.1016/j.eneco.2018.08.017

Etokakpan, M. U., Adedoyin, F. F., Vedat, Y., \& Bekun, F. V. (2020). Does globalization in Turkey induce increased energy consumption: insights into its environmental pros and cons. Environmental Science and Pollution Research.

Halkos, G. E., \& Tzeremes, N. G. (2013). Carbon dioxide emissions and governance: A nonparametric analysis for the G-20. Energy Economics, 40, 110-118. https://doi.org/10.1016/j.eneco.2013.06.010

Hargrove, A., Qandeel, M., \& Sommer, J. M. (2019). Global governance for climate justice : A cross-national analysis of CO 2 emissions. Global Transitions, 1, 190-199. https://doi.org/10.1016/j.glt.2019.11.001

Hashmi, R., \& Alam, K. (2019). Dynamic relationship among environmental regulation, innovation, $\mathrm{CO} 2$ emissions, population, and economic growth in OECD countries: A panel investigation. Journal of Cleaner Production, 231, 1100-1109. https://doi.org/10.1016/j.jclepro.2019.05.325

Kirikkaleli, D., Adedoyin, F. F., \& Bekun, F. V. (2020). Nuclear energy consumption and economic growth in the UK: Evidence from wavelet coherence approach. Journal of Public Affairs, February, 1-11. https://doi.org/10.1002/pa.2130 
Knapp, T. (1996). Population growth and global CO 2 emissions A secular perspective. 24(1), 31-37.

Ma, M., Saidi, K., Ben, M., \& Asia, S. (2020). Heliyon Economic growth in South Asia: the role of CO 2 emissions , population density and trade openness. 6(March). https://doi.org/10.1016/j.heliyon.2020.e03903

Omri, A., \& Bel Hadj, T. (2020). Foreign investment and air pollution: Do good governance and technological innovation matter? Environmental Research, 185(February), 109469. https://doi.org/10.1016/j.envres.2020.109469

Sarkodie, S. A., Adams, S., \& Leirvik, T. (2020). Foreign direct investment and renewable energy in climate change mitigation: Does governance matter? Journal of Cleaner Production, 121262. https://doi.org/10.1016/j.jclepro.2020.121262

Satterthwaite, D., Dodman, D., \& Grubler, A. (2009). The implications of population growth and urbanization for climate change E N VIR O N M E N T \& UR B A N I Z AT I O N. 21(2), 545-567. https://doi.org/10.1177/0956247809344361

Udi, J., Bekun, F. V., \& Adedoyin, F. F. (2020). Modeling the nexus between coal consumption, FDI inflow and economic expansion: does industrialization matter in South Africa? Environmental Science and Pollution Research. https://doi.org/10.1007/s11356-020-07691-x

Wr, S., \& Birdsall, N. (1992). Another Look at Population and Global Warming.

Zhou, Y., \& Liu, Y. (2016). Does population have a larger impact on carbon dioxide emissions than income? Evidence from a cross-regional panel analysis in China. Applied Energy, 180, 800-809. https://doi.org/10.1016/j.apenergy.2016.08.035

Zhu, Q., \& Peng, X. (2012). The impacts of population change on carbon emissions in China during 1978 - 2008. Environmental Impact Assessment Review, 36, 1-8. https://doi.org/10.1016/j.eiar.2012.03.003

\section{Appendix}

Table A.1 List of Countries in the sample

\begin{tabular}{|l|l|}
\hline Angola & Kenya \\
\hline Benin & Lesotho \\
\hline Botswana & Liberia \\
\hline Burkina Faso & Madagascar \\
\hline Burundi & Malawi \\
\hline Cameroon & Mali \\
\hline Cape Verde & Mauritania \\
\hline Central African Republic & Mauritius \\
\hline
\end{tabular}




\begin{tabular}{|l|l|}
\hline Chad & Mozambique \\
\hline Comoros & Namibia \\
\hline Democratic Republic of the Congo & Niger \\
\hline Eritrea & Nigeria \\
\hline Ethiopia & Republic of the Congo \\
\hline Gabon & Rwanda \\
\hline Gambia & Sao Tome and Principe \\
\hline Ghana & Senegal \\
\hline Guinea & Seychelles \\
\hline Guinea-Bissau & Sierra Leone \\
\hline Ivory Coast & Somalia \\
\hline & South Africa \\
\hline & Sudan \\
\hline & Tanzania \\
\hline & Zimbabwe \\
\hline
\end{tabular}

383

384

385 